\title{
Spatial variations in nitrogen dioxide concentrations in urban Ljubljana, Slovenia
}

\author{
Katja VINTAR MALLY a , Matej OGRIN a
}

\begin{abstract}
Ambient nitrogen dioxide $\left(\mathrm{NO}_{2}\right)$ concentrations are regularly measured at only two monitoring stations in the city centre of Ljubljana, and such scanty data are inadequate for drawing conclusions about spatial patterns of pollution within the city, or to decide on effective measures to further improve air quality. In order to determine the spatial distribution of $\mathrm{NO}_{2}$ concentrations in different types of urban space in Ljubljana, two measuring campaigns throughout the city were carried out, during the summer of 2013 and during the winter of 2014. The main source of $\mathrm{NO}_{2}$ in Ljubljana is road transport. Accordingly, three types of urban space have been identified (urban background, open space along roads, and street canyon), and their $\mathrm{NO}_{2}$ pollution level was measured using Palmes diffusive samplers at a total of 108 measuring spots. This article analyses the results of both measuring campaigns and compares the pollution levels of different types of urban space.
\end{abstract}

Keywords: road transport, air pollution, nitrogen dioxide, diffusive samplers, Ljubljana, Slovenia

\section{Introduction}

Air pollution from road transport in urban areas is a serious problem, both in central cities as well as elsewhere in urban regions, as the traffic volume and congestion on roads are increasing. Nitrogen oxides are among the most important pollutants produced by transport and are released as fuel is burned in internal combustion engines, as well as in industrial and energy production processes. The group of nitrogen oxides $\left(\mathrm{NO}_{\mathrm{x}}\right)$ includes nitrogen monoxide (NO) and nitrogen dioxide $\left(\mathrm{NO}_{2}\right)$. Nitrogen oxides have a negative impact on human health, particularly on liver, lung and spleen functions, and on the blood as well (EU-28 - Air pollution fact sheet 2014,2014 , p. 3).

Nitrogen oxide emissions also contribute to acid rain and the eutrophication of water and soil (EU-28 - Air pollution fact sheet 2014, 2014, p. 3), and are a significant component of photochemical smog, which affects the formation of ozone. In 2012, $45 \%$ of nitrogen oxide emissions in the European Union came from transport, and 39\% of it from road transport. Transport is thus the second most important source of this pollutant, after energy production (ibid., p. 6). During this same time period, $8 \%$ of the urban population was exposed to excessively high concentrations of nitrogen dioxide; this figure, however, is $5.1 \%$ lower than in 2010 (ibid., p. 10).

In Slovenia air quality is further diminished by poor ventilation in low-lying areas, especially in the cities in the interior of the country. Ljubljana is among these poorlyventilated cities, where there are no steady strong winds, which reduces the self-cleaning capacity of the air. Since it is located in a basin, temperature inversions during times of clear weather are frequent and pronounced (Ogrin, 2010; Ogrin and Plut, 2009). Recent data indicate that emissions from transport in Slovenia have been reduced, but transport nevertheless remains one of the major sources of air pollution.
In 2012, road transport contributed 53\% of nitrogen oxide emissions (Logar, 2014; Slovenia - Air pollution fact sheet 2014,2014, p. 6), and the whole transport sector: 55\% (Logar, 2014). But judging from official data from the national air quality monitoring network, the urban population in Slovenia in the 2010-2012 period was not exposed to excessive concentrations of nitrogen dioxide (Slovenia - Air pollution fact sheet 2014, 2014, p. 10). It should be noted, however, that these estimates are based on only six monitoring stations in the urban environment of Slovenia. This means that these data do not capture the heterogeneity of urban space, which is usually high. There are many different types of land use in urban areas, settlement is dense, and the density of roads and other transport routes is high as well. It is therefore necessary to set up a dense network of measuring points, and to repeat these measurements many times, in order to gain an accurate picture of spatial pollution patterns and of the change in concentrations in urban space.

In this article we closely examine nitrogen dioxide air pollution in Ljubljana in the summer 2013 and the winter 2014, using a much denser spatial network. Similar studies in the past have indicated that in this way a rather different and, above all, a more complete picture of air pollution in the urban environment can be obtained. A study of nitrogen dioxide pollution in Genoa thus showed that concentrations in particular areas of the city can differ from the average values by more than $70 \%$ (Gallelli et al., 2002). Fluctuations in concentrations are also high in smaller areas, as can be seen from a study of air quality at Aberdeen Harbour (Marr et al., 2007): average concentrations in summer were in a range from 15 to $36 \mathrm{ppb} / \mathrm{v}$, and this was in a relatively small area. Similar studies have also been conducted in the area of Ljubljana in the past (Ogrin et al., 2006; Ogrin, 2008; Ogrin and Vintar Mally, 2013), in which the findings were similar and serve to confirm the thesis regarding the need

\footnotetext{
${ }^{a}$ Department of Geography, Faculty of Arts, Ljubljana, Slovenia (*corresponding author: Katja Vintar Mally, e-mail:katja.vintar@ff.uni-lj.si)
} 


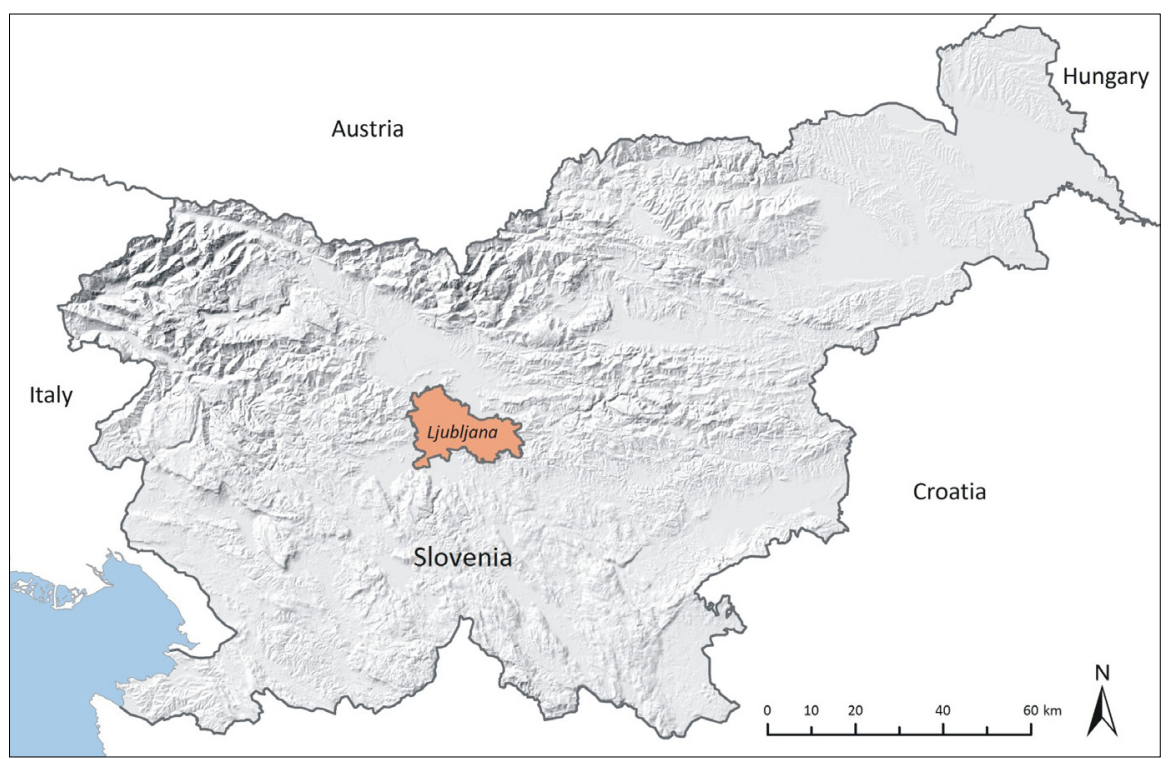

Fig. 1: Research area - the location of the City Municipality of Ljubljana (orange coloured area). Source: GURS, 2012

for a dense spatial network of measuring points, especially in urban environments. This article shows the air pollution in Ljubljana in summer 2013 and winter 2014 in a dense spatial network in different types of urban space using the method of diffusive samplers (in literature also referred to as diffusion tubes or passive diffusion samplers).

\section{Theoretical background and methods}

The use of diffusive samplers to identify spatial patterns of pollution in Ljubljana has already been shown by earlier studies (Ogrin et al., 2006; Ogrin, 2008) to be a suitable method for determining air quality, and we therefore also used them in the 2013/2014 study presented here, thereby enabling easier comparability of our results with those of previous investigations.

Diffusive samplers are used to sample certain substances in the air through passive sampling, and are therefore also called passive samplers. This means that we do not need pumps for the supply of air into the samplers: they are simply exposed to the air. The level of sampling is monitored through the level of diffusion of the pollutant in the air within the sampler, as determined by Fick's law of diffusion, which accounts for the name of the sampler.

There are several different types of diffusive samplers; in our study we used Palmes samplers, which have been in use since the 1970s (Palmes et al., 1976). They have a $7.1 \mathrm{~cm}$ long tube with an internal cross-sectional area of $0.71 \mathrm{~cm}^{2}$ and a metal mesh at the closed end coated with a reagent that acts as a sorbent. At one end the tube is closed and at the other end it is open during the sampling period. Outside air enters through this opening during the time of sampling, bringing with it also pollutants. When the pollutant in the tube reaches the membrane and reacts with the reagent, a new substance is formed that remains on the membrane. Thus the concentration of the pollutant that is being sampled is equal to zero in the immediate vicinity of the membrane, since the sorbent binds it to itself and changes it. A gradient of concentration is therefore always formed in the tube whenever the concentration of the sampled pollutant of the entering air is greater than zero, and due to molecular diffusion this causes a flow of molecules towards the membrane with the reagent. At the end of the sampling the sampler closes, and the membranes are sent for chemical analysis, where the mass and hence also average concentration of the pollutant is determined by chemical analytical methods.

It is worth noting some of the important advantages of the method of sampling using diffusive samplers, in particular their flexibility and practicality. The samplers are simple and quick to set up and this can be performed by one person. The samplers and shelters are small, lightweight, and durable when cared for properly. Several hundred can be set up in one day, which greatly increases the quality of information on air pollution and also enables a dense spatial grid of measurements. Because of their low cost, we can repeat the measuring campaign frequently and more easily tolerate losses of samplers due to vandalism (Cape, 2009; Ogrin and Vintar Mally, 2013, p. 58).

On the other hand we must also consider the disadvantages of carrying out measurements and interpreting results using this sampling method. First of all we are interested in the comparability of this method with the reference method. The use of diffusive samplers compared with the reference method approved by the European Commission was performed by Warren Spring Laboratory (Campbell et al., 1994) and researchers found that the use of diffusive samplers gave about $30 \%$ higher values, with the differences being higher in more heavily polluted environments. A possible source of the elevated concentrations could be wind effects, shortening the diffusion path in the diffusion tube (Campbell et al., 1994). Several studies (Heal et al., 1999; Heal and Cape, 1997) show the higher concentrations of nitrogen dioxide to be the result of change in the atmospheric photostationary state within the tube, where there is a reaction between nitrogen monoxide and ozone that is no longer balanced by the dissociation of nitrogen dioxide. In a study in Edinburgh Heal and Cape (1997) found that in urban areas this excess reached $28 \%$ in summer, while in rural areas and in winter in urban areas it was 8-14\%. On the other hand, Moschandreas et al. (1990) note that low temperatures (251-283 K) lead to an underestimation of $\mathrm{NO}_{2}$ concentrations due to anomalies in the behaviour of triethanolamine below the freezing point for this substance, which is at $294 \mathrm{~K}$. 
The time at which the samplers are exposed can also influence measurement results. Bush et al. (2001) cite cases of studies in which four-week concentrations were noticeably lower than two-week ones, especially in the summer months. Among other things, this is assumed to be the result of the photodegradation of triethanolamine, which is more pronounced in the warm and sunny summer months. On average over a six-month period, four-week samples had a value that was $18 \%$ lower than two-week ones. Based on their own research, these authors found that for areas with an urban background the differences among measurements with diffusive samplers and the reference chemiluminescent measurements in longer periods, were within the general uncertainties of the chemiluminiscent measurements, and so corrective factors of the values measured in the diffusive samplers are not required. The authors further found that the use of shelters and shaded samplers, which reduce the penetration of turbulence into the diffusive sampler, also affect the lower overestimation of the concentrations measured.

A disadvantage of the method using diffusive samplers is also the fact that they provide only information about average pollution, and not maximum, hourly, multi-hourly, or daily values on which legally determined threshold values are based. Moreover, the method is not suitable for monitoring air quality in real time, since the results are available only after a time lag, once the final chemical analysis of the samplers has been performed, and this can last from several days to several weeks.

Measurement based on the use of the Palmes diffusive samplers is also less suitable for shorter periods; it must last for at least a few days and preferably for one to three weeks, during which time there can also be a problem due to the photodegradation of the reagent in the sampler, as mentioned above.

In the research described here as well as in previous studies, we placed the samplers in special shelters made by the manufacturer of the samplers (Gradko International) (Fig. 2), which reduces turbulence in the area surrounding the sampler and consequently also inside it. After both measuring campaigns, the samplers were sent to the Gradko International laboratory for chemical analysis. "Nitrogen dioxide is absorbed as nitrite by triethanolamine. Nitrite reacts with the added reagent to form a reddish purple azo dye, which is measured spectrophotometrically (ultraviolet/visible) at 542 nanometres. Concentrations as $\mu \mathrm{g}$ on tube are calculated by reference to a nitrite calibration curve prepared from certified reference standards. The concentrations are converted to $\mathrm{ugm}^{3}$ and parts per billion nitrogen dioxide in air using exposure data and a constant derived from the coefficient of diffusion and sampling rate" (Gradko Environmental, 2015).

The measurement uncertainty, as specified by the laboratory, was in both cases $\pm 7.8 \%$. The details of the Nitrogen Dioxide Proficiency Scheme for the year 2014 provided by Gradko International, are specified in Table 1.

During each campaign, a set of three blank (unexposed) samplers was used and sent for analysis in order to subtract the values of blank samplers from the results of the exposed samplers. Additionally, the results were always corrected using a correction factor obtained from the relationship between the values measured with the six diffusive samplers and the reference method at the Ljubljana city monitoring station of the Slovenian Environment Agency. The

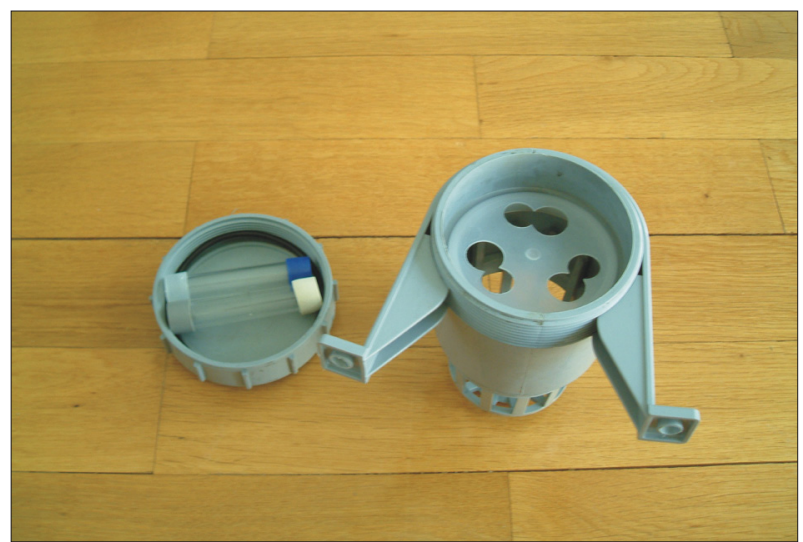

Fig. 2: Diffusive samplers and shelter (Photo: M. Ogrin)

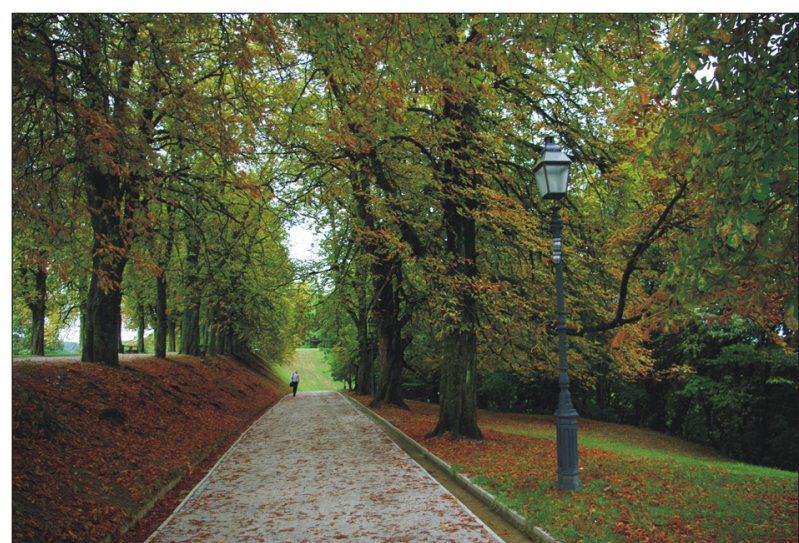

Fig. 3: Measuring point in the urban background at Ljubljana Castle (Photo: K. Vintar Mally)

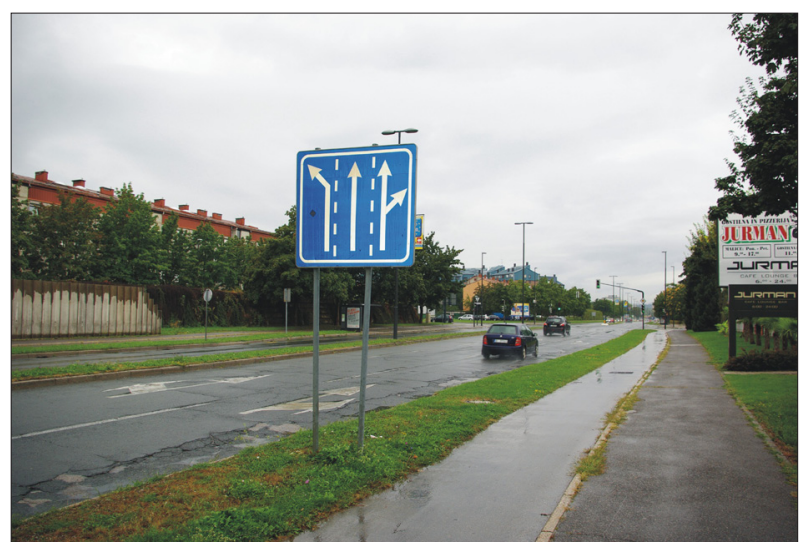

Fig. 5: The measuring point along Zaloška Street was classified as the type open space along roads (Photo: K. Vintar Mally)

correction factor for the summer campaign was small (1.07) and, as such, also within the measurement uncertainty. The correction factor for the winter campaign turned out to be larger, reaching 1.27.

Since the research area is rather small (around 6-9 km in diameter) and the reference monitoring station is almost in the middle of this area, we have decided to use this correction factor for all measurements. We are aware, however, of the possibility that these factors could somewhat differ across the whole network. At each measuring spot the shelter (containing three diffusive samplers) was mounted on a streetlight, a traffic sign, a traffic light, the roof gutter of buildings or in similar place. Samplers along roads were placed at a height of about three meters from the ground, 


\begin{tabular}{|c|c|c|c|c|c|c|c|c|}
\hline \multicolumn{9}{|c|}{ Proficiency scheme - Nitrogen dioxide 2014} \\
\hline \multirow[b]{2}{*}{ Date } & \multirow{2}{*}{ Round } & \multirow{2}{*}{$\begin{array}{l}\text { Assigned } \\
\text { value }\end{array}$} & \multicolumn{3}{|c|}{ Camspec M550 - GLM 7} & \multicolumn{3}{|c|}{ QuAAttro-GLM 9} \\
\hline & & & $\begin{array}{c}\text { Measured } \\
\text { concentration }\end{array}$ & z-Score & $\%$ Bias & $\begin{array}{c}\text { Measured } \\
\text { concentration }\end{array}$ & z-Score & $\%$ Bias \\
\hline Feb-14 & WASP 124-1 & 0.90 & 0.91 & 0.14 & 1.2 & 0.91 & 0.06 & 0.6 \\
\hline Feb-14 & WASP 124-2 & 2.24 & 2.25 & 0.09 & 0.5 & 2.31 & 0.41 & 2.9 \\
\hline Feb-14 & WASP 124-3 & 2.24 & 2.25 & 0.07 & 0.4 & 2.33 & 0.58 & 4.2 \\
\hline Feb-14 & WASP $124-4$ & 0.90 & 0.93 & 0.46 & 2.9 & 0.92 & 0,32 & 1.9 \\
\hline May-14 & AIR PT 1-1 & 1.39 & 1.44 & 0.48 & 3.6 & 1.43 & 0.38 & 2.9 \\
\hline May-14 & AIR PT 1-2 & 1.36 & 1.44 & 0.78 & 5.9 & 1.40 & 0.39 & 2.9 \\
\hline May-14 & AIR PT 1-3 & 0.97 & 0.95 & -0.27 & -2.1 & 0.98 & 0.14 & 1.0 \\
\hline May-14 & AIR PT 1-4 & 0.99 & 0.97 & -0.27 & -2.0 & 0.99 & 0.00 & 0.0 \\
\hline Aug-14 & AIR PT 3-1 & 1.84 & 1.84 & 0.00 & 0.0 & 1.87 & 0.22 & 1.6 \\
\hline Aug-14 & AIR PT 3-2 & 1.71 & 1.71 & 0.00 & 0.0 & 1.72 & 0.08 & 0.6 \\
\hline Aug-14 & AIR PT 3-3 & 1.66 & 1.65 & -0.08 & -0.6 & 1.69 & 0.24 & 1.8 \\
\hline Aug-14 & AIR PT 3-4 & 1.83 & 1.87 & 0.29 & 2.2 & 1.88 & 0.36 & 2.7 \\
\hline Nov-14 & AIR PT 4-1 & 2.00 & 1.99 & -0.07 & -0.5 & 2.05 & 0.33 & 2.5 \\
\hline Nov-14 & AIR PT 4-2 & 1.98 & 1.95 & -0.20 & -1.5 & 2.01 & 0.20 & 1.5 \\
\hline Nov-14 & AIR PT 4-3 & 1.15 & 1.15 & 0.00 & 0.0 & 1.16 & 0.12 & 0.9 \\
\hline Nov-14 & AIR PT 4-4 & 1.14 & 1.14 & 0.00 & 0.0 & 1.15 & 0.12 & 0.9 \\
\hline
\end{tabular}

Tab. 1: Proficiency Scheme for $\mathrm{NO}_{2}$ measurements in year 2014. Methods: GLM 7-Camspec M550 Spectrophotometer, GLM 9-QuAAtro Continuous Flow analyser.

Source: Gradko Environmental, 2014

usually $0.5-3.0 \mathrm{~m}$ from the edge of the road, exceptionally even more. After the chemical analysis, the average value of nitrogen dioxide concentration at each measuring spot was calculated, using only the nearest two measured values and excluding the third one. This allowed for the exclusion of unusually large or small values, which can occur from unknown or known reasons (for example contamination from the ingress of insects or spiders).

In Ljubljana, measuring points were determined with respect to three pre-defined types of urban space: urban background, open space along roads, and street canyons (see Fig. 6, below). For measuring points in the urban background, it is the case that sources do not affect the flow of concentrations directly but rather with a lag. Daily fluctuations in pollutants are significantly lower than along roads (where there are fluctuations in the degree of traffic congestion), and the average concentrations are lower. These areas are usually residential neighbourhoods, parks, gardens and similar places, and are usually more distant from major roads and other sources that would directly affect the path of concentrations. Any pollution in these areas is an especially important problem, since people spend time in them more frequently and for longer periods, including spending their free time there, and such areas are generally regarded by people to be more peaceful and less polluted. With respect to pollution from primary pollutants, these areas are usually less polluted.

Street canyons are a particular spatial category (Figs. 4a,bsee cover p. 4). They are narrow, densely built-up or walled areas, usually in city centres, where arterial roads converge in squares and large parking areas, or lead to a major road that runs through the centre of the city. Traffic is often congested and slow-moving along street canyons. Although they usually have a lower volume of traffic than arterials on the outskirts of the city or ring roads, they are nonetheless quite busy. Since the self-cleaning capacity of the air in street canyons is severely diminished, the concentrations of primary pollutants are greater, and in some places very high. It is also important to note that nitrogen dioxide is only partly a primary pollutant. Only about $10 \%$ of this gas is exhausted directly from vehicles, the rest is produced with oxidation of nitrogen monoxide and ozone. In street canyons, ozone concentrations are often too small to react with all the nitrogen monoxide available. Eventually, nitrogen monoxide reaches the urban background, where it usually reacts with ozone to create nitrogen dioxide. This can result in lower concentrations of nitrogen dioxide in street canyons than what one might expect.

For the third type we placed measuring points in open space along roads. Sampling was performed along arterial and other roads outside street canyons in order to gain an insight into the air quality and its degree of pollution from nitrogen dioxide along roads where pollutants are not concentrated due to topography, but pollution is instead dependent on the volume of traffic and the speed of vehicles using them.

\section{Results and discussion}

Measurements of nitrogen dioxide using diffusive samplers were carried out in the city of Ljubljana over three weeks in the summer of 2013 (from 26 $6^{\text {th }}$ August 


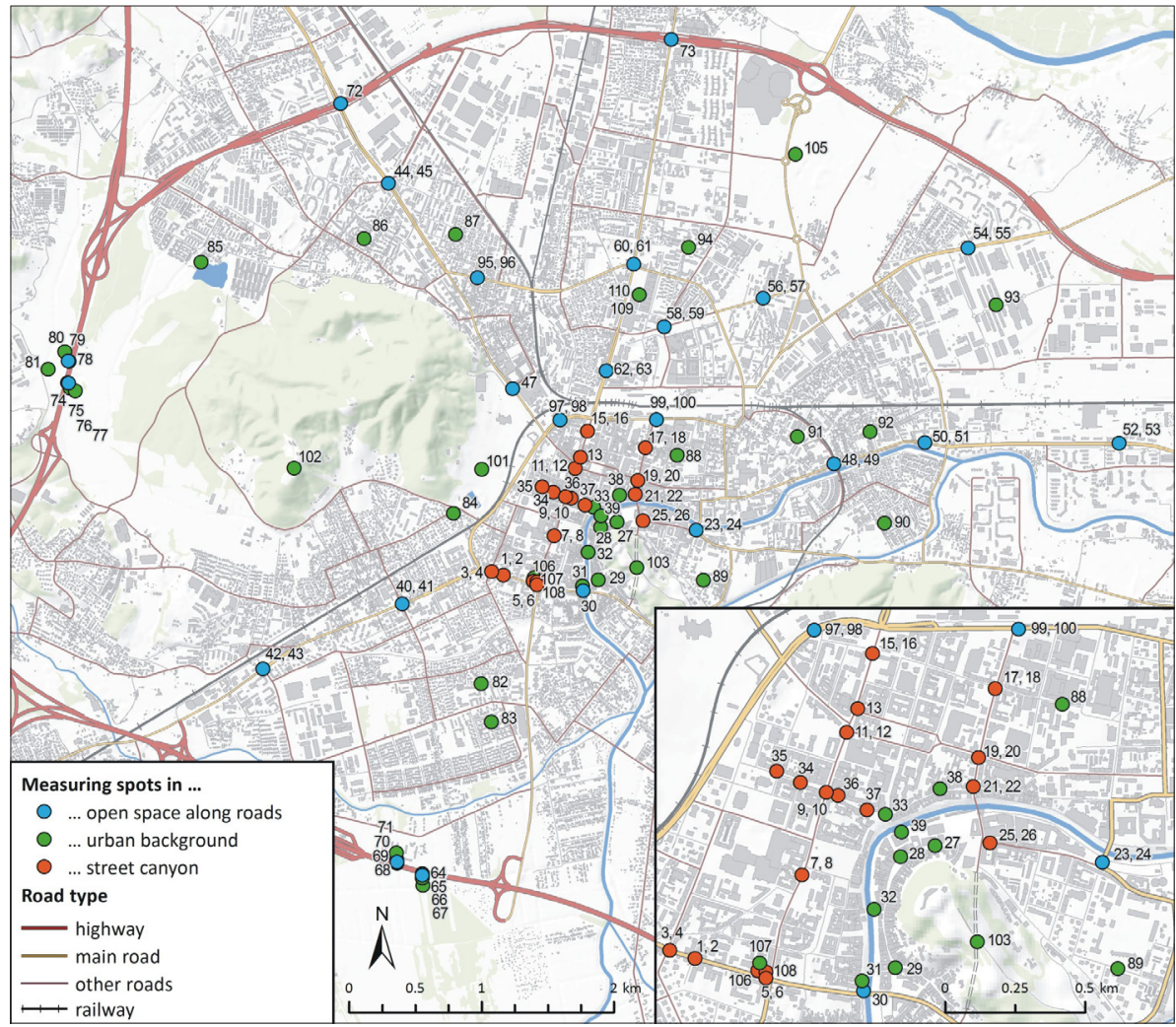

Fig. 6: Measuring spots for nitrogen dioxide in the summer and winter measuring campaigns in Ljubljana Sources: GURS, 2012 and MKGP, 2013 for GIS data; authors' survey for $\mathrm{NO}_{2}$ measurements

to $16^{\text {th }}$ September 2013), and for three weeks in winter 2014 (from $15^{\text {th }}$ January to $6^{\text {th }}$ February 2014), at 108 different measuring spots, classified into the three pre-defined types of urban space (Fig. 6). In the urban background, the sampling was conducted at 35 measuring spots, in the open space along roads at 43 measuring spots (of which in 16 cases measuring spots were paired in locations along both sides of a main road, while the remaining spots were distributed in the immediate vicinity of the ring road), and in street canyons at 30 measuring spots (likewise in pairs on both sides of the street, with the exception of four locations along pedestrian zones in the city centre and one location where we further placed samplers at two different heights above the main road). In the cases where the measuring spots were placed in a pair on each side of the street (in street canyons as well as in open space along roads), we combined them into one measuring point. The concentration of nitrogen dioxide for these measuring points was calculated as the arithmetic mean of the concentrations from each measuring spot in the pair. In this way, we eliminated the influence of wind on the final value along the road. Since wind in the urban background and at a greater distance from main roads does not have a significant influence on the result of the measurement, measuring points there were composed of just one measuring spot.

In this account we provide the results of measurements of nitrogen dioxide for 35 measuring points in the urban background (Fig. 7), 27 measuring points in open space along roads (Fig. 8) and 18 measuring points in street canyons (Fig. 9). For both measurement campaigns we

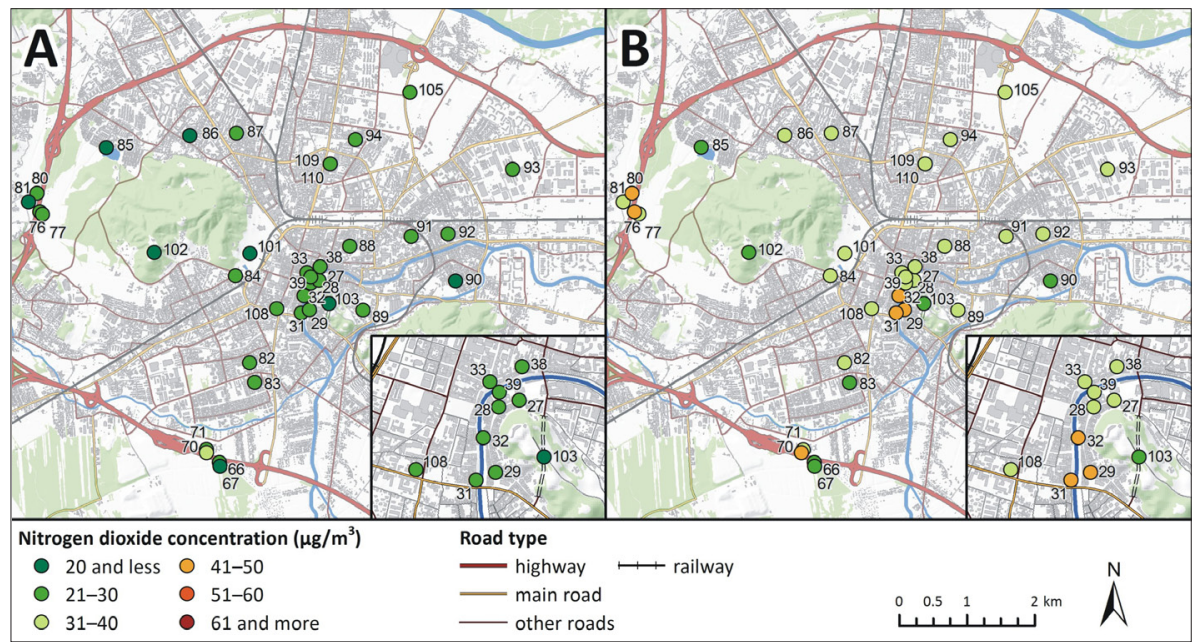

Fig. 7: Concentrations of nitrogen dioxide in the urban background in the summer (A) and winter (B) measuring campaigns. Sources: GURS, 2012 and MKGP, 2013 for GIS data; authors' survey for $\mathrm{NO}_{2}$ concentrations 


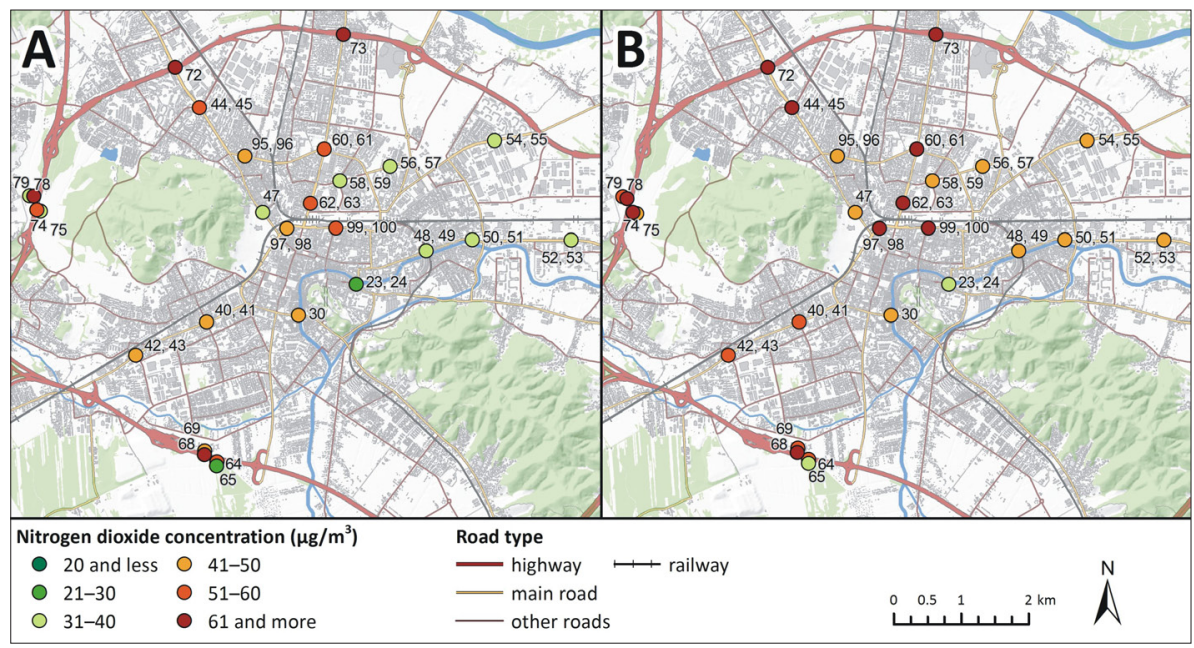

Fig. 8: Concentrations of nitrogen dioxide in open space along roads in the summer (A) and winter (B) measuring campaigns. Sources: GURS, 2012 and MKGP, 2013 for GIS data; authors' survey for $\mathrm{NO}_{2}$ concentrations

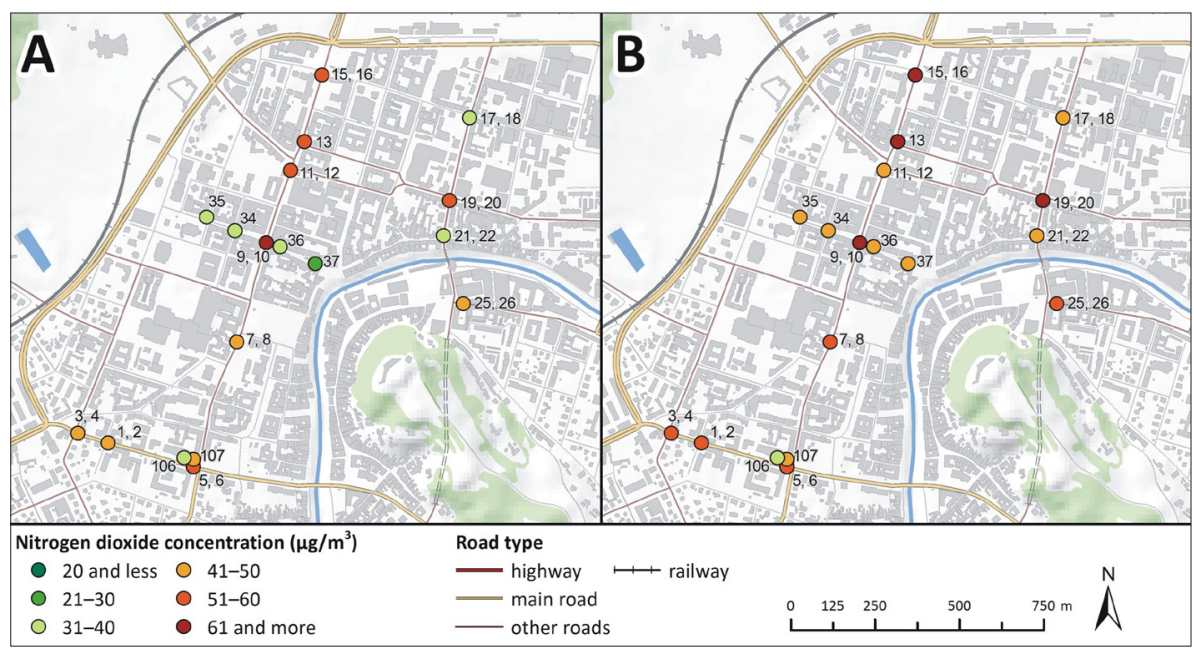

Fig. 9: Concentrations of nitrogen dioxide in street canyons in the summer (A) and winter (B) measuring campaigns Sources: GURS, 2012 and MKGP, 2013 for GIS data; authors' survey for $\mathrm{NO}_{2}$ concentrations

\begin{tabular}{|c|c|c|c|c|}
\hline \multirow[b]{2}{*}{ Type of urban space } & \multicolumn{2}{|c|}{ Concentrations $\left(\mu \mathbf{g} / \mathbf{m}^{3}\right)$} & \multirow{2}{*}{$\begin{array}{l}\text { Absolute difference } \\
\qquad\left(\mu \mathrm{g} / \mathbf{m}^{3}\right)^{* *}\end{array}$} & \multirow{2}{*}{$\begin{array}{l}\text { Relative difference } \\
\qquad(\%)^{* * *}\end{array}$} \\
\hline & $\begin{array}{c}\text { Summer } \\
\text { measurements }\end{array}$ & $\begin{array}{c}\text { Winter } \\
\text { measurements }\end{array}$ & & \\
\hline \multicolumn{5}{|l|}{ Urban background } \\
\hline Highest value & 31 & 45 & 19 & 112 \\
\hline Lowest value & 15 & 23 & 2 & 8 \\
\hline Average of all measuring points & 23 & 35 & 11 & 50 \\
\hline \multicolumn{5}{|l|}{ Open space along roads } \\
\hline Highest value & 67 & 81 & 22 & 65 \\
\hline Lowest value & 29 & 37 & 3 & 7 \\
\hline Average of all measuring points & 46 & 56 & 9 & 22 \\
\hline \multicolumn{5}{|l|}{ Street canyons* } \\
\hline Highest value & 72 & 67 & 12 & 27 \\
\hline Lowest value & 38 & 45 & -7 & -10 \\
\hline Average of all measuring points & 52 & 57 & 5 & 11 \\
\hline
\end{tabular}

Tab. 2: Comparison of nitrogen dioxide concentrations in the summer and winter measuring campaigns in different types of urban space in Ljubljana. Note: *Altogether 12 measuring points in four street canyons (Aškerčeva, Slovenska, Resljeva, and Poljanska street canyon) with motor vehicle traffic were taken into account (Fig. 9); **Absolute difference $=$ winter concentration - summer concentration; $* * *$ Relative difference $=$ (winter concentration - summer concentration)/summer concentration $\times 100$

Source: authors' survey and calculations 
make use of the results for 106 different locations, since measuring spots 109 and 110 were placed in the same location (directly adjacent to the automatic reference station of the Slovenian Environment Agency, in order to check the accuracy of measurements). Measuring spots at locations 14 and 46 are not included in the comparison; the diffusive samplers there were stolen during one of the measuring campaigns. Measuring point 104 could not be set up. The measured values of the concentrations of nitrogen dioxide in the summer and winter measuring campaigns can (with respect to the duration of the measurements) be compared only with the annual threshold value $\left(40 \mu \mathrm{g} / \mathrm{m}^{3}\right)$, which is the only determined threshold value for nitrogen dioxide under Slovenian law for a period longer than one or three hours (Bolte and Murovec, 2013, p. 9).

Measuring points for the urban background were located in city parks and recreation areas, in the pedestrian zone in the city centre, side streets in peaceful residential neighbourhoods, and other areas where people often gather and spend their free time, since city residents generally believe that these areas are less polluted. At a greater distance from main roads, daily fluctuations in the concentrations of pollutants are in fact lower and the levels of concentrations are also lower. Thus in the summer as well as the winter measuring campaign, the lowest values of concentrations of nitrogen dioxide in Ljubljana were measured in the urban background: in summer these were from 15 to $31 \mu \mathrm{g} / \mathrm{m}^{3}$, and in winter from 23 to $45 \mu \mathrm{g} / \mathrm{m}^{3}$ (Tab. 2). In the summer measuring campaign the concentrations measured were nowhere higher than the annual threshold value of $40 \mu \mathrm{g} / \mathrm{m}^{3}$, but in the winter measuring campaign this occurred at six measuring points, in the city centre and near the city ring road (Fig. 7). The fact that in winter concentrations of nitrogen dioxide in the urban background, with the exception of seven measuring points, were everywhere higher than $30 \mu \mathrm{g} / \mathrm{m}^{3}$, including in the city park of Tivoli (measuring point 101) and in the pedestrian zone in the city centre (for example, measuring points $27,28,29,32,33$ ), is a cause for concern. In both measuring campaigns the lowest concentrations were measured in the city districts of Koseze (85) and Kodeljevo (90), and on two hills above the city - on Rožnik (102) and on Castle Hill (103). These two measuring points also indicate lower concentrations of nitrogen dioxide in somewhat higher layers of the air or, rather, the retention of polluted air at ground level.

Higher concentrations of nitrogen dioxide were measured at all measuring points in the urban background in the winter measuring campaign than in the summer measuring campaign, greater on average by $50 \%$, or $11 \mu \mathrm{g} / \mathrm{m}^{3}$. The difference is alarmingly high, although it is in any case expected since winter weather conditions reduce the selfcleaning capacity of the air in the city and increase the use of energy for heating; fuel consumption by vehicles is also higher. The winter air pollution measured at background level indicates a generally present pollution of the air in the city, even far from sources of pollution, which practically cannot be avoided, and it is also a sort of basic level of pollution in street canyons and along other roads.

The second type of measuring points covered locations in open space along roads that are the most heavily travelled in Ljubljana. Measurements were conducted along the city ring road, arterials and other main roads that do not have the characteristics of a street canyon. In this type of space, air pollution is dependent on the number and type of vehicles and their speed. In the summer measuring campaign concentrations of nitrogen dioxide measured in open space along roads were from 29 to $67 \mu \mathrm{g} / \mathrm{m}^{3}$, and in the winter measuring campaign from 37 to $81 \mu \mathrm{g} / \mathrm{m}^{3}$. In summer the average concentration in open space along roads $\left(46 \mu \mathrm{g} / \mathrm{m}^{3}\right)$ was twice the average concentration in the urban background $\left(23 \mu \mathrm{g} / \mathrm{m}^{3}\right)$, while the winter average concentration of $56 \mu \mathrm{g} / \mathrm{m}^{3}$ in open space along roads almost reached the average concentration of nitrogen dioxide of the most heavily polluted type, i.e. street canyons (Tab. 2).

The concentrations measured in open space along roads exceeded the legally defined annual threshold value of $40 \mu \mathrm{g} / \mathrm{m}^{3}$ at two-thirds of the measuring points in summer and at 25 measuring points of a total of 27 in winter. The highest concentrations were measured along the city arterials Celovška Street (measuring points 72, 44-45) and Dunajska Street (73, 60-61, 62-63) and directly beside the ring road $(64,68,74,78)$, as well as along the main bus station in the city centre (99-100). In this type of measuring points we also included two so-called 'hot spots' in the investigation measuring points 72 and 73, where a city arterial runs above the ring road and the concentrations of nitrogen dioxide were among the highest in both measuring campaigns, as expected. In the winter measuring campaign the highest values in the whole of the study were measured at these two locations: $81 \mu \mathrm{g} / \mathrm{m}^{3}$ at measuring point 72 and $78 \mu \mathrm{g} / \mathrm{m}^{3}$ at measuring point 73 .

The other main roads in the city, along which non-motorized traffic also travels, are immediately adjacent as bicycle paths and sidewalks usually run right alongside, and they were also found to be relatively heavily polluted, especially in winter. Thus pedestrians and cyclists, in addition to car and bus passengers, are also exposed to excessive concentrations of nitrogen dioxide.

In the centre of Ljubljana we identified several street canyons, characterized by dense, slow-moving traffic through a space along the street with a high density of buildings, usually tall. Although they normally have a lower volume of traffic than arterials on the outskirts of the city or ring roads, high concentrations of primary pollutants are to be expected because of the poor self-cleaning capacities of the air in the canyon. For nitrogen dioxide, which is mainly a secondary pollutant, higher concentrations are expected only if enough ozone is available for the reaction with nitrogen monoxide as the primary air pollutant. Measuring points were set up in four street canyons along which traffic flows: the Aškerčeva street canyon (measuring points 1-2, 3-4, 5-6), the Slovenska street canyon (7-8, 9-10, 11-12, 13, 15-16), the Resljeva street canyon (17-18, 19-20, 21-22), and the Poljanska street canyon (25-26). A fifth canyon was selected for comparison, between Cankarjeva Street and Copova Street $(34,35,36,37)$, which is for the most part closed to automobile traffic, but this traffic runs along cross streets, including Slovenska Street. Concentrations measured in this canyon were indeed considerably lower than in other canyons, reaching 27 to $36 \mu \mathrm{g} / \mathrm{m}^{3}$ in summer and 41 to $48 \mu \mathrm{g} \mathrm{m}{ }^{3}$ in winter (Fig. 9).

The average winter and summer concentrations of nitrogen dioxide obtained from the other four street canyons showed that street canyons are the most polluted type of urban space. On average the most polluted was the Slovenska street canyon, where the highest summer concentration in the city was also measured $\left(72 \mu \mathrm{g} / \mathrm{m}^{3}\right.$ at measuring point 9-10). In the winter of 2014 measured concentrations increased in comparison to summer values at all measuring points in street canyons, except for measuring 
points $9-10$ and 11-12 in the Slovenska street canyon, since the city closed this section of road to passenger cars in the fall of 2013, and since that time only public transit and deliveries are permitted. Concentrations of nitrogen dioxide in the canyon mentioned nevertheless significantly exceeded the annual threshold value, which also holds true for the other street canyons in winter.

Only in the Resljeva street canyon in summer were concentrations lower at two measuring points, amounting to $38 \mu \mathrm{g} / \mathrm{m}^{3}$ (measuring point 21-22) and $39 \mu \mathrm{g} / \mathrm{m}^{3}$ (measuring point 17-18). In the Aškerčeva street canyon at measuring point 5-6, diffusive samplers were also exceptionally mounted at heights of 11 meters (measuring point 106) and 26 meters (107) above the street, in order to observe how concentrations of nitrogen dioxide in the street canyon change in a vertical direction. In both measuring campaigns, the concentration fell significantly with increasing height: in winter, for example, from $59 \mu \mathrm{g} / \mathrm{m}^{3}$ at a height of three meters to $41 \mu \mathrm{g} / \mathrm{m}^{3}$ at 11 meters above the street, and $31 \mu \mathrm{g} / \mathrm{m}^{3}$ at 26 meters above the street. Future studies will need to give greater attention to these types of measurements since not only pedestrians, cyclists, and users of motorized transport are endangered, but also residents and employees in nearby buildings, who are exposed to elevated concentrations for many hours a day.

\section{Conclusions}

Measurements of nitrogen dioxide taken using diffusive samplers in the city of Ljubljana in the summer of 2013 and winter of 2014 showed heavy pollution of the air in certain parts of the city, and also great variety in the degree of pollution, which confirms the thesis on the need for a dense spatial network of measurements.

In general, concentrations in both measuring campaigns were lowest in the urban background and highest in street canyons, although measuring points in the open space along roads category on average did not show a significantly more favourable situation than that in the street canyons. It should be emphasized, however, that the air quality in open space along roads is strongly dependent on the volume of traffic, and pollution along roads that are not busy can be very low. But in a street canyon the air becomes strongly polluted even with a considerably lower volume of traffic, and this pollution just increases as traffic increases. In Ljubljana the air was most polluted from nitrogen dioxide along arterial roads (especially at overpasses above the ring road), directly adjacent to the ring road, and in the centre of the city where there are street canyons, the area around the main bus station and the main roads with the most traffic. We also found a relatively high level of nitrogen dioxide concentrations in the urban background, as a result of which, for example, in winter the air was constantly polluted at a level of about $35 \mu \mathrm{g} / \mathrm{m}^{3}$, and the contamination increases with the proximity of local sources of pollution, as shown by measurements in the space along more heavily travelled roads and in street canyons.

Here it should be emphasized that measurements in both measuring campaigns took place in rather untypical weather conditions that were more supportive of the self-cleaning capacities of the air, with above average precipitation, greater mixing of air, and an absence of longer temperature inversions, and in winter it was also unusually warm. As a result, we expect significantly greater pollution of the air than that measured, especially in winter, with stable, calm, and colder anticyclonic weather. The latter is also supported by the comparison of winter concentrations of nitrogen dioxide as measured in three consecutive years with the reference method at the Ljubljana city monitoring station of the Slovenian Environment Agency. Although the Agency has in 2014 temporarily moved the monitoring station from its usual place for about $650 \mathrm{~m}$, it remained in the same type of urban space (i.e. urban background) with similar characteristics and without any important influence on the results. Over the same three-week period in winter 2013 and winter 2015, the average concentrations of nitrogen dioxide were $40 \mu \mathrm{g} / \mathrm{m}^{3}$, which is $25 \%$ higher than during our measuring campaign in winter $2014\left(32 \mu \mathrm{g} / \mathrm{m}^{3}\right)$. This is not only indicative of the meteorological conditions in the winter of 2014 but also supports the conclusion that average conditions may usually be worse than those presented in this discussion.

High concentrations of nitrogen dioxide are a caution to the city of Ljubljana and the country of Slovenia, drawing attention to the urgency of implementing measures for sustainable mobility: for example, expansion of the bicycle path network, reduction of parking areas for private cars, strengthening (the competitiveness of) public transit, encouragement of walking and non-motorized traffic, education of the population, preparation of mobility plans for public institutions, etc. Above all, perhaps, this work points to the need for restrictions on traffic in the city centre, the introduction of vehicles with cleaner technologies, especially for public transit, and for spatial planning that will protect road users and residents from the negative impacts of polluted air and raise the general quality of life in the city.

\section{Acknowledgement}

This study would not have been possible without the support of the Urban Municipality of Ljubljana and the Anton Melik Geographical Institute of the Research Centre of the Slovenian Academy of Sciences and Arts, or the assistance of the Slovenian Environment Agency (special thanks to Anton Planinšek) and the Department of Geography, Faculty of Arts, University of Ljubljana (we would like to thank students Valentina Pajk, Simon Koblar, Petra Udrih and Nejc Bobounik).

\section{References:}

BOLTE, T., MUROVEC, M. (2013): Zakonodaja. In: Koleša, T. [ed.]: Kakovost zraka v Sloveniji v letu 2012 (pp. 8-10). Ljubljana, Ministrstvo za kmetijstvo in okolje, Agencija Republike Slovenije za okolje.

BUSH, T., SMITH, S., STEVENSON, K., MOORCROFT, S. (2001): Validation of nitrogen dioxide diffusion tube methodology in the UK. Atmospheric Environment, 35(2): 289-296.

CAMPBELL, G. W., STEDMAN, J. R., STEVENSON, K. (1994): A survey of nitrogen dioxide concentrations in the United Kingdom using diffusion tubes, July-December 1991. Atmospheric Environment, 28(3): 477-486.

CAPE, J. N. (2009): The Use of Passive Diffusion Tubes for Measuring Concentrations of Nitrogen Dioxide in Air. Critical Reviews in Analytical Chemistry, 39(4): 289-310.

EUROPEAN UNION (EU-28) - AIR POLLUTION FACT SHEET 2014 (2014), Copenhagen, European 
Environment Agency, 16 pp. [online] [cit. 30.11.2014]. Available at: http://www.eea.europa.eu/themes/air/airpollution-country-fact-sheets-2014/eu-27-air-pollutantemissions/view

GALLELLI, G., ORLANDO, P., PERDELLI, F., PANATTO, D. (2002): Factors affecting individual exposure to $\mathrm{NO}_{2}$ in Genoa (northern Italy). Science of the Total Environment, 287(1-2): 31-36.

GRADKO ENVIRONMENTAL (2014): Nitrogen Dioxide Proficiency Scheme 2014.

GRADKO ENVIRONMENTAL (2015): Nitrogen Dioxide Diffusion Tube Analysis.

GURS - Geodetska uprava Republike Slovenije (2012): Gospodarska javna infrastruktura in Kataster stavb (GIS data).

HEAL, M. R., CAPE, J. N. (1997): A numerical evaluation of chemical interferences in the measurement of ambient nitrogen dioxide by passive diffusion samplers. Atmospheric Environment, 31(13): 1911-1923.

HEAL, M. R., O'DONOGHUE, M. A., CAPE, J. N. (1999): Overestimation of urban nitrogen dioxide by passive diffusion tubes: a comparative exposure and model study. Atmospheric Environment, 33(4): 513-524.

LOGAR, M. (2014): Izpusti onesnaževal zraka iz prometa. Kazalci okolja v Sloveniji. Agencija Republike Slovenije za okolje [online] [cit. 30.11.2014]. Available at: http:// kazalci.arso.gov.si/?data=indicator\&ind_id $=616$

MARR, I. L., ROSSER, D. P., MENESES, C. A. (2007): An air quality survey and emissions inventory at Aberdeen Harbour. Atmospheric Environment, 41(30): 6379-6395.

MKGP - Ministrstvo za kmetijstvo, gozdarstvo in prehrano (2013): Dejanska raba tal (GIS data).
MOSCHANDREAS, D. J., RELWANI, S. M., TAYLOR, K. C., MULIK, J.D. (1990): A laboratory evaluation of a nitrogen dioxide personal sampling device. Atmospheric Environment, 24A(11): 2807-2811.

OGRIN, D. (2010): Physical-geographical factors relevant for the development of Ljubljana. In: Krevs, M. et al. [eds.]: Challenges of spatial development of Ljubljana and Belgrade (pp. 27-36). GeograFF 8. Ljubljana, Znanstvena založba Filozofske fakultete.

OGRIN, D., PLUT, D. (2009): Aplikativna fizična geografija Slovenije. Ljubljana, Znanstvena založba Filozofske fakultete.

OGRIN, D., OGRIN, M., ČEMAS, D., PLANINŠEK, A. (2006): Prometno onesnaževanje ozračja $\mathrm{v}$ Ljubljani znotraj avtocestnega obroča. Končno poročilo raziskovalnega projekta. Ljubljana, Filozofska fakulteta, Oddelek za geografijo.

OGRIN, M. (2008): Prometno onesnaževanje ozračja z dušikovim dioksidom v Ljubljani. GeograFF 1. Ljubljana, Znanstvena založba Filozofske fakultete, Oddelek za geografijo.

OGRIN, M., VINTAR MALLY, K. (2013): Primerjava poletne onesnaženosti zraka $\mathrm{z}$ dušikovim dioksidom v Ljubljani med letoma 2005 in 2013. Dela, 40: 55-72.

PALMES, E. D., GUNNISON, A. F., DiMATTIO, J., TOMCZYK, C. (1976): Personal sampler for nitrogen dioxide. American Industrial Hygiene Association Journal, 37(10): 570-577.

SLOVENIA - AIR POLLUTION FACT SHEET 2014 (2014), Copenhagen, European Environment Agency, 16 pp. [online] [cit. 30.11.2014]. Available at: http://www.eea.europa.eu/ themes/air/air-pollution-country-fact-sheets-2014/sloveniaair-pollutant-emissions-country-factsheet/view

Initial submission 4 January 2015, final acceptance 1 July 2015

Please cite this article as:

VINTAR MALLY, K., OGRIN, M. (2015): Spatial variations in nitrogen dioxide concentrations in urban Ljubljana, Slovenia. Moravian Geographical Reports, 23(3): 27-35. DOI: 10.1515/mgr-2015-0015. 